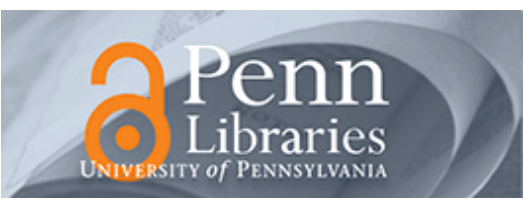

University of Pennsylvania ScholarlyCommons

April 2007

\title{
Adhesion of MC3T3-E1 cells to RGD peptides of different flanking residues: Detachment strength and correlation with long-term cellular function
}

\author{
Mark H. Lee \\ University of Pennsylvania \\ Christopher S. Adams \\ Thomas Jefferson University \\ David Boettiger \\ University of Pennsylvania \\ William F. DeGrado \\ University of Pennsylvania \\ Irving M. Shapiro \\ University of Pennsylvania, ishap@biochem.dental.upenn.edu
}

See next page for additional authors

Follow this and additional works at: https://repository.upenn.edu/mse_papers

\section{Recommended Citation}

Lee, M. H., Adams, C. S., Boettiger, D., DeGrado, W. F., Shapiro, I. M., Composto, R. J., \& Ducheyne, P. (2007). Adhesion of MC3T3-E1 cells to RGD peptides of different flanking residues: Detachment strength and correlation with long-term cellular function. Retrieved from https://repository.upenn.edu/mse_papers/ 120

In press, Journal of Biomedical Materials Research Part A, Volume 81A, Issue 1, April 2007, Pages 150-160.

Publisher URL: http://dx.doi.org/10.1002/jbm.a.31065

This paper is posted at ScholarlyCommons. https://repository.upenn.edu/mse_papers/120

For more information, please contact repository@pobox.upenn.edu. 


\title{
Adhesion of MC3T3-E1 cells to RGD peptides of different flanking residues: Detachment strength and correlation with long-term cellular function
}

\begin{abstract}
We synthesized a series of RGD peptides and immobilized them to an amine-functional self-assembled monolayer using a modified maleimide-based conjugate technique that minimizes nonspecific interactions. Using a spinning disc apparatus, a trend in the detachment strength ( $\tau_{50}$ ) of RGD peptides of different flanking residues was found: RGDSPK $>$ RGDSVVYGLR $\approx$ RGDS $>$ RGES. Using blocking

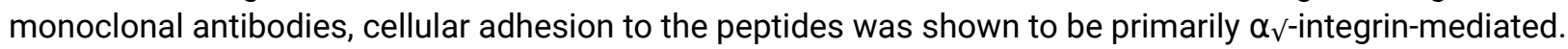
In contrast, the $\tau_{50}$ value of the cells on fibronectin (Fn)-coated substrates of similar surface density was 6-7 times higher and involved both $\alpha_{5} \beta_{1}$ and $\alpha_{\nu} \beta_{3}$ integrins. Cellular spreading was enhanced on RGD peptides after $1 \mathrm{~h}$ when compared to RGE and unmodified substrates. However, no significant differences were observed between the different RGD peptides. Long-term function of MC3T3-E1 cells was also evaluated by measuring alkaline phosphatase (ALP) activity and mineral deposition. Among the four peptides, RGDSPK exhibited the highest level of ALP activity after 11 days and mineralization after 15 days and reached comparable levels as Fn substrates after 15 and 24 days, respectively. These findings collectively illustrate both the advantages and limitations of enhancing cellular adhesion and function by the design of RGD peptides.
\end{abstract}

\section{Keywords}

RGD peptide, osteoblast, cell adhesion, flanking residues, mineralization

\section{Comments}

In press, Journal of Biomedical Materials Research Part A, Volume 81A, Issue 1, April 2007, Pages 150-160.

Publisher URL: http://dx.doi.org/10.1002/jbm.a.31065

\section{Author(s)}

Mark H. Lee, Christopher S. Adams, David Boettiger, William F. DeGrado, Irving M. Shapiro, Russell J. Composto, and Paul Ducheyne 
Lee, MH; Adams, CS; Boettiger, D; DeGrado, WF; Shapiro, IM; Composto RJ; Ducheyne, P., 2007, Adhesion and function of MC3T3-E1 cells on RGD peptides of different flanking residues: Detachment strength and correlation with long-term cellular function, JOURNAL OF BIOMEDICAL MATERIALS RESEARCH, PT.A., IN PRESS.

\section{Adhesion of MC3T3-E1 cells to RGD peptides of}

\section{different flanking residues: Detachment strength and}

\section{correlation with long-term cellular function}

Mark H. Lee,,${ }^{a, d,}$ Christopher S. Adams, ${ }^{c}$ David Boettiger, ${ }^{e}$ William F. DeGrado, ${ }^{f}$ Irving M.

$$
\text { Shapiro, }{ }^{c, d} \text { Russell J. Composto, }{ }^{a, b, d} \text { and Paul Ducheyne, }{ }^{a, d}
$$

Department of Bioengineering, Center for Bioactive Materials \& Tissue Engineering,

Department of Materials Science \& Engineering, Department of Microbiology, Department of

Biochemistry \& Molecular Biophysics. University of Pennsylvania, Philadelphia, PA 19104.

Department of Orthopaedic Surgery, Thomas Jefferson University, Philadelphia, PA 19107.

* To whom correspondence should be addressed. Phone: (215) 898-9824. Fax: (215) 573-2071.

E-mail: markhl@alumni.upenn.edu

${ }^{a}$ Department of Bioengineering, University of Pennsylvania.

${ }^{\mathrm{b}}$ Department of Materials Science \& Engineering, University of Pennsylvania

${ }^{\mathrm{c}}$ Department of Orthopedic Surgery, Thomas Jefferson University

${ }^{\mathrm{d}}$ Center for Bioactive Materials \& Tissue Engineering, University of Pennsylvania

${ }^{\mathrm{e}}$ Department of Microbiology, University of Pennsylvania

${ }^{\mathrm{f}}$ Department of Biochemistry and Molecular Biophysics, University of Pennsylvania 
Lee, MH; Adams, CS; Boettiger, D; DeGrado, WF; Shapiro, IM; Composto RJ; Ducheyne, P., 2007, Adhesion and function of MC3T3-E1 cells on RGD peptides of different flanking residues: Detachment strength and correlation with long-term cellular function, JOURNAL OF BIOMEDICAL MATERIALS RESEARCH, PT.A., IN PRESS.

\begin{abstract}
We synthesized a series of RGD peptides and immobilized them to an amine-functional selfassembled monolayer using a modified maleimide-based conjugate technique which minimizes non-specific interactions. Using a spinning disc apparatus, a trend in the detachment strength $\left(\tau_{50}\right)$ of RGD peptides of different flanking residues was found: RGDSPK $>$ RGDSVVYGLR $\approx$ RGDS > RGES. Using blocking monoclonal antibodies, cellular adhesion to the peptides was shown to be primarily $\alpha_{\mathrm{v}}$-integrin-mediated. In contrast, the $\tau_{50}$ value of the cells on fibronectin (Fn) coated substrates of similar surface density was 6-7 times higher and involved both $\alpha_{5} \beta_{1}$ and $\alpha_{\mathrm{v}} \beta_{3}$ integrins. Cellular spreading was enhanced on RGD peptides after $1 \mathrm{~h}$ in comparison to RGE and unmodified substrates. However, no significant differences were observed between the different RGD peptides. Long-term function of MC3T3-E1 cells was also evaluated by measuring alkaline phosphatase (ALP) activity and mineral deposition. Among the four peptides, RGDSPK exhibited the highest level of ALP activity after 11 days and mineralization after 15 days and reached comparable levels as Fn substrates after 15 and 24 days respectively. These findings collectively illustrate both the advantages and limitations of enhancing cellular adhesion and function by the design of RGD peptides.
\end{abstract}

Keywords: RGD peptide, osteoblast, cell adhesion, flanking residues, mineralization 
Lee, MH; Adams, CS; Boettiger, D; DeGrado, WF; Shapiro, IM; Composto RJ; Ducheyne, P., 2007, Adhesion and function of MC3T3-E1 cells on RGD peptides of different flanking residues: Detachment strength and correlation with long-term cellular function, JOURNAL OF BIOMEDICAL MATERIALS RESEARCH, PT.A., IN PRESS.

\section{INTRODUCTION}

Orthopedic tissue engineering constructs can be modified with immobilized bioactive molecules to enhance osseointegration. Engineered peptide motifs derived from adhesive proteins present in the extracellular matrix (ECM) of bone, such as fibronectin, bone sialoprotein and osteopontin, have been immobilized on material substrates in order to improve the adhesion and function of a number of osteoblastic cell lines. Most commonly, these peptides contain the arginine-glycine-aspartic acid (RGD) sequence which interacts specifically with integrin receptors. Once the peptide is bound to its cognate receptor, a number of critical signal transduction pathways are activated that in turn modulate cell function.[1]

Recent studies using RGD peptides immobilized on amine-functional self-assembled monolayers (SAM) demonstrated increases in the adhesion, spreading and mineralization of murine [2,3] and rat [4,5] calvarial osteoblast-like cells. These model substrates are useful in studying interactions between peptides/proteins and cells in a controlled, homogeneous physicochemical environment.[6] However, the high density of amine functional groups present on these substrates can also promote strong, non-specific interactions with the cell membrane that confound accurate prediction of the peptide effect.[7] Thus, to increase understanding of the parameters which modulate the bioactivity of the immobilized RGD peptide, it is necessary to be able to both detect and minimize these confounding interactions.

To address the problem discussed above, we first use a spinning disc apparatus to quantify the non-specific and specific contributions of bone cells on immobilized RGD peptides. A maleimide heterobifunctional crosslinker that allows for a selective conjugation with $-\mathrm{NH}_{2}$ and SH groups of peptides [8,9] was applied to 3-aminopropyltriethoxysilane (APTES) SAMs. A large, residual non-specific interaction was identified on these maleimide-functional substrates that could be minimized by a simple modification of the attachment chemistry. Then, we synthesized and quantified the detachment strength of a series of modularly designed peptides which contain the following cell binding domains: RGDS, RGDSPK (a fragment from fibronectin, Fn); and RGDSVVYGLR (a 10-mer derived from osteopontin). The different RGD peptides were selected because they have shown promise for use in orthopedic tissue engineering 
Lee, MH; Adams, CS; Boettiger, D; DeGrado, WF; Shapiro, IM; Composto RJ; Ducheyne, P., 2007, Adhesion and function of MC3T3-E1 cells on RGD peptides of different flanking residues: Detachment strength and correlation with long-term cellular function, JOURNAL OF BIOMEDICAL MATERIALS RESEARCH, PT.A., IN PRESS.

applications. For example, (G)RGDSPK has been used to inhibit rat bone cell attachment and mineralization on Fn-coated substrates when soluble[10,11] and to increase the adhesion of rat calvarial osteoblast adhesion when immobilized on polystyrene or acellular bone matrix.[12] RGDSVVYGLR is a sequence derived from osteopontin, a bone matrix protein, and is known to bind with high affinity to $\alpha_{v} \beta_{3}$ integrins[13] receptors present in high concentrations on the surface of cultured osteoblasts.[14-16] Using this system, we investigated differences in the detachment strength of MC3T3-E1 cells to peptides of varying flanking residues. The adhesion mediated by the peptides is compared to that of the full Fn protein in terms of difference in detachment strength and in the integrin(s) involved. We then investigated the correlation of the trend in the adhesion among the peptides with both short-term (spreading) and long-term function of these osteoblast-like cells. More specifically, the long-term function was evaluated by measuring changes in ALP activity, a commonly used indicator of MC3T3-E1 differentiation, and the deposition of a calcified mineralized extracellular matrix.

\section{MATERIALS AND METHODS}

\section{Substrate Preparation}

The preparation and characterization of self-assembled monolayers (SAMs) of 3aminopropyltriethoxysilane (APTES) and glycidoxypropyltrimethoxysilane (GPTMS) were previously described in detail.[7] Briefly, silicon wafers (p-type, $<1-0-0>$ orientation, 20-30 $\Omega$ $\mathrm{cm}$ resistivity) were cut into samples of $1.2 \mathrm{~cm}$ x $1.2 \mathrm{~cm}$ and were cleaned with piranha solution (3:1 (v:v) $\mathrm{H}_{2} \mathrm{SO}_{4} / \mathrm{H}_{2} \mathrm{O}_{2}$ ). After thoroughly rinsing with ultrapure water (18 $\mathrm{M} \Omega$-cm resistivity), the substrates were dried with nitrogen and then exposed to UV-Ozone for $10 \mathrm{~min}$. SAM deposition was performed by immersion of the samples into either 5\% (v:v) APTES or 20\% (v:v) GPTMS solution in toluene for $16 \mathrm{~h}$ under anhydrous conditions. Subsequently, the samples were sonicated in toluene, N,N'-dimethylformamide (DMF) and water. After fabrication, GPTMS samples were immersed in $2.75 \mathrm{mM} \beta$-mercaptoethanol ( $\beta \mathrm{ME})$ in phosphate buffer solution (PBS, $\mathrm{pH}$ 7.4) for $16 \mathrm{~h}$ and sonicated twice with ultrapure $\mathrm{H}_{2} \mathrm{O}$ to produce $\mathrm{OH}$ SAMs.[17]

Peptide-immobilized substrates were fabricated using an adaptation of the protocol used by Xiao et al.[18] APTES SAMs were immersed and sonicated in $5.0 \mathrm{mM}$ solution of $\beta$ - 
Lee, MH; Adams, CS; Boettiger, D; DeGrado, WF; Shapiro, IM; Composto RJ; Ducheyne, P., 2007, Adhesion and function of MC3T3-E1 cells on RGD peptides of different flanking residues: Detachment strength and correlation with long-term cellular function, JOURNAL OF BIOMEDICAL MATERIALS RESEARCH, PT.A., IN PRESS.

maleimidopropionic acid N-hydroxysuccinimide ester (BMPS) in acetonitrile for $1 \mathrm{~h}$, followed by sonication in acetonitrile, acetone, and ultrapure water (20 min each). Unreacted amines on the substrates were acetylated using a 1:1:1:2 molar solution of acetic acid: 1hydroxybenzotriazole $\quad(\mathrm{HOBt}): \quad \mathrm{N}-[(1 \mathrm{H}-$ benzotriazol-1-yl)(dimethylamino)methylene $]-\mathrm{N}-$ methylmethanaminium hexafluorophosphate N-oxide (HBTU): N,N-diisopropylethylamine (DIEA) in DMF for $1 \mathrm{~h}$. After sonication in DMF and water, the acetylation and sonication procedure was repeated. Lastly, these substrates were immersed in the peptide solution in Dulbecco's PBS (0.1 M sodium phosphate, $0.15 \mathrm{M} \mathrm{NaCl}, \mathrm{pH} 7.2)$ for $1.5 \mathrm{~h}$. at room temperature. The concentration of the peptide solution was varied to achieve the same surface density (6 $\mathrm{pmol} / \mathrm{cm}^{2}$ ), as determined from radiolabeling results. Unreacted maleimides were subsequently blocked using a 1mM $\beta$ ME solution in PBS for $30 \mathrm{~min}$. A two-fold molar excess of Tris(2carboxyethyl)phosphine (TCEP) was added to both the peptide and $\beta \mathrm{ME}$ solutions to maintain the thiol groups in their reactive, reduced state. All samples were sonicated in fresh PBS twice and used immediately.

\section{Surface Characterization}

Each step of the surface modification process was verified by monitoring the increase in the substrate thickness using an AutoEl-II Null Ellipsometer (Rudolph Research, Flanders NJ) at a fixed incident angle of 70 degrees with a helium-neon laser source $(\lambda=632.8 \mathrm{~nm})$. Thicknesses were calculated using the manufacturer-provided DAFIBM program using the following refractive indices: $\mathrm{SiO}_{2}=1.462, \quad$ APTES $=1.423, \mathrm{BMPS} /$ Acetyl $=1.5$. The value of 1.5 represents a generic value for organic materials with unknown refractive indices.[19]

Sessile drop contact angle measurements were taken using a goniometer setup built in-house containing a Hamilton microsyringe and a CCD camera. A constant drop volume (10 $\mu \mathrm{L})$ of ultrapure water was gently deposited onto the surface and allowed to grow prior to slow needle retraction and image collection. The captured images were analyzed using Scion Image (Scion Corporation, Frederick MD) to determine the contact angles. All readings were performed immediately after sample preparation to minimize contamination. 
Lee, MH; Adams, CS; Boettiger, D; DeGrado, WF; Shapiro, IM; Composto RJ; Ducheyne, P., 2007, Adhesion and function of MC3T3-E1 cells on RGD peptides of different flanking residues: Detachment strength and correlation with long-term cellular function, JOURNAL OF BIOMEDICAL MATERIALS RESEARCH, PT.A., IN PRESS.

\section{Design and Synthesis of RGD peptides}

A modular peptide design was used in order to be able to achieve both specific attachment and quantification of surface coverage. The following peptides were synthesized using standard protocols used for Fmoc-based SPPS [20] with an Applied Biosystems 433A peptide synthesizer using a Wang resin pre-loaded with the first amino acid ( $0.63 \mathrm{mmole} / \mathrm{g}$ substitution) on a 0.25 mmol rxn scale: Ac-CYGGRGDS-OH, Ac-CYGGRGDSVVYGLR-OH, Ac-CYGGRGDSPK$\mathrm{OH}$ and Ac-CYGGRGES-OH. The peptides were cleaved from the resin using an 82.5/5/5/5/2.5 (by vol.) mixture of trifluoroacetic acid/thioanisole/water/anisole/ethanedithiol, precipitated in excess cold diethyl ether and purified by reverse-phase HPLC using a linear 1\%/min acetonitrile gradient at a $10 \mathrm{~mL} / \mathrm{min}$ flow rate on a Vydac preparative C4 HPLC column. The fractions were lyophilized and identified using MALDI-TOF mass spectrometry with $\alpha$-cyano-4hydroxycinnamic acid matrix and angiotensin and insulin as the molecular weight standards. The molecular weight of the four synthesized peptides, RGDS, RGDSPK, RGDSVVYGLR and RGES, were verified to be $855,1081,1543$ and $868 \mathrm{~g} / \mathrm{mol}$ respectively.

\section{Determination of Peptide Surface Density}

Radiolabeled peptide studies were conducted by iodinating the Tyr residues of the RGD peptides. $2 \mathrm{mg}$ of the peptide was dissolved in $0.5 \mathrm{~mL}$ of PBS solution, the $\mathrm{pH}$ adjusted to 7.4 and added to an Iodo-Gen tube (Pierce) along with approximately 0.5 mCurie of $\mathrm{Na}^{125} \mathrm{I}$ The reaction was allowed to occur for $10 \mathrm{~min}$. at room temperature under gentle shaking. TCEP was only added to the peptide solution after the radiolabeling step. The radiolabeled peptide was purified by collecting the appropriate fractions from a $5 \mathrm{~mL}$ size exclusion chromatography column packed with reconstituted Sephadex G-10 Gel. A $5 \mu \mathrm{L}$ aliquot was counted using a Wizard 1470 automatic gamma counter and the $\mathrm{OD}_{280}$ was determined by UV-Vis Spectrophotometry. The molar activity was determined using the following calculated molar extinction coefficient for the peptides: $\varepsilon_{280}$ (RGDS, RGES, RGDSPK) $=1400 \mathrm{M}^{-1} \cdot \mathrm{cm}^{-1}, \varepsilon_{280}$ $($ RGDSVVYGLR $)=2680 \mathrm{M}^{-1} \cdot \mathrm{cm}^{-1}$. The protocol for radiolabeling of affinity-purified human plasma fibronectin (Fn) is described in detail elsewhere.[17,21] 
Lee, MH; Adams, CS; Boettiger, D; DeGrado, WF; Shapiro, IM; Composto RJ; Ducheyne, P., 2007, Adhesion and function of MC3T3-E1 cells on RGD peptides of different flanking residues: Detachment strength and correlation with long-term cellular function, JOURNAL OF BIOMEDICAL MATERIALS RESEARCH, PT.A., IN PRESS.

\section{Cell Culture}

MC3T3-E1 newborn calvaria pre-osteoblasts (subclone 4, ATCC CRL-2593) were maintained in complete medium consisting of Dulbecco's Modified Eagle's Medium (DMEM) with 10\% fetal bovine serum, $2 \mathrm{mM}$ L-glutamine and $50 \mu \mathrm{g} / \mathrm{mL}$ penicillin/streptomycin using standard cell culture techniques. Cells of low passage (p14 - p18) were used to avoid decreased proliferative and differentiative capability which has been reported for this cell line at high passage numbers.[22] Cells were released with $0.25 \%$ Trypsin-EDTA for 5 min., washed with complete medium and with serum-free medium. Cells were seeded at a density of $1 \cdot 10^{5}$ cells/well in 12 well bacteriological plates containing the ethanol-sterilized samples $\left(1.2 \times 1.2 \mathrm{~cm}^{2}\right.$ each). The high seeding density was necessary due to the inefficiency of attachment of cells to the silicon samples which were smaller than the well. Although the samples were opaque and therefore not amenable to phase contrast imaging, parallel experiments with fluorescently labeled cells confirmed that the attached cells were sparsely distributed on all substrates (less than 50\% confluency) and had enough room to spread and proliferate. The cells were allowed to attach in serum-free medium overnight $(12 \mathrm{~h})$; this was replaced with complete medium at day 1 . At day 3 , the media was replaced with complete medium supplemented with $10 \mu \mathrm{g} / \mathrm{mL}$ ascorbic acid and $10 \mathrm{mM} \beta$-glycerophosphate. The concentration of ascorbic acid was gradually increased to $50 \mu \mathrm{g} / \mathrm{mL}$ by day 7 and was maintained for the remainder of the experiment, with media exchanges every 2-3 days. After 8, 11 and 15 days in culture, the attached cells were trypsinized, scraped with a wide mouth pipette tip, rinsed with media and pelletized by centrifugation.

\section{Spinning Disc Measurements}

The various surfaces were prepared on $2.54 \mathrm{~cm}$ diameter silicon substrates that could be mounted on stages designed for the spinning disc apparatus, as described previously.[23] MC3T3-E1 cells were trypsinized, rinsed with complete medium and serum-free DMEM and diluted appropriately. For the blocking experiments, cells were incubated further for $30 \mathrm{~min}$. in either the anti- $\alpha_{v}$ mAb (RMV-7, Chemicon) [24-26] and/or anti- $\alpha_{5} \beta_{1}$ mAb (BMA-5, Chemicon) $[27,28]$ at a concentration of 1:100. Each sample was seeded with $2.0 \times 10^{5}$ cells/disc in $1 \mathrm{~mL}$ of serum-free DMEM. After $15 \mathrm{~min}$. at $37^{\circ} \mathrm{C}$ in complete medium, the samples were spun for 5 
Lee, MH; Adams, CS; Boettiger, D; DeGrado, WF; Shapiro, IM; Composto RJ; Ducheyne, P., 2007, Adhesion and function of MC3T3-E1 cells on RGD peptides of different flanking residues: Detachment strength and correlation with long-term cellular function, JOURNAL OF BIOMEDICAL MATERIALS RESEARCH, PT.A., IN PRESS.

min. at room temperature in adhesion buffer (24 mM HEPES, $137 \mathrm{mM} \mathrm{NaCl}, 2.7 \mathrm{mM} \mathrm{KCl,} 1$ $\mathrm{mM} \mathrm{MgCl}$, and $1 \mathrm{mM}$ glucose, $\mathrm{pH} \mathrm{7.4)} \mathrm{at} \mathrm{the} \mathrm{appropriate} \mathrm{angular} \mathrm{velocity} \mathrm{to} \mathrm{develop} \mathrm{a} \mathrm{good}$ detachment profile. The detachment profile was insensitive to the experimental conditions in the spinning disc chamber due to the short duration of exposure. Under these attachment conditions, cells have sufficient time to attach through specific interactions without significant spreading, which can complicate the interpretation of the measurements due to cell spreading and flattening. The ramp up to the final speed ( 1 min.) and the duration of exposure (5 min.) with the spinning disc apparatus have both been optimized to ensure that the majority of the cells were detached at the periphery of the disc (i.e. maximum $\tau$ ) without exposing the cells to a long duration of shear force which can induce cellular changes in itself.

After the spinning disc experiment, the samples were fixed with $3.7 \%$ formaldehyde solution, permeabilized with $1 \%$ Triton X-100 and stained with ethidium homodimer. Rather than determining the adherent cell fraction after exposure to one detachment force as in other adhesion assays, the number of attached cells was recorded at different disc radii (i.e. different forces) and converted into adherent cell fraction by normalization to the number of cells without exposure to the detachment force (at $r=0$ ). The relationship for shear stress is given by the following equation: $\tau=0.800 \cdot r \cdot(\rho \mu \omega)^{0.5}$ where $r$ and $\mu$ are the disc radius and angular velocity. $\rho$ and $\mu$ are hydrodynamic constants for the media. The data was then analyzed using SigmaPlot v 2000 to sigmoidally curve-fit the profile. The critical cell detachment strength $\left(\tau_{50}\right)$ determined by this analysis represents the shear stress at which $50 \%$ of the cells remain attached and served as the metric for comparison between substrates. It should be noted that 61 separate microscope fields (10 X) were counted per sample (3-4 fields for a given radius for a total of 10,000-20,000 cells per sample) and that 10 samples were typically analyzed per substrate type (from 3 separate experiments). Detachment profiles and the resulting $\tau_{50}$ values from representative substrates of two different levels of adhesiveness is included as Fig. 1 for clarity.

\section{Cell Spreading}

Fluorescent microscopy of DiI-labeled cells was used to determine the spreading area of the cells after 15 min., $1 \mathrm{~h}, 2.5 \mathrm{~h}$ and $5 \mathrm{~h}$ after attachment. The DiI-labeled cells were seeded on the substrates at a density of $1.0 \times 10^{5}$ cells $/ \mathrm{mL}$ in serum-free DMEM. MetaMorph v. 4.6 was used 
Lee, MH; Adams, CS; Boettiger, D; DeGrado, WF; Shapiro, IM; Composto RJ; Ducheyne, P., 2007, Adhesion and function of MC3T3-E1 cells on RGD peptides of different flanking residues: Detachment strength and correlation with long-term cellular function, JOURNAL OF BIOMEDICAL MATERIALS RESEARCH, PT.A., IN PRESS.

to measure the spread area of the cells. A minimum of 5 separate $20 \mathrm{x}$ fields were analyzed per substrate.

\section{Alkaline Phosphatate (ALP) Activity}

The level of ALP activity was determined using the AttoPhos AP Fluorescent Substrate System. The collected cell pellet was resuspended in ice cold $0.9 \% \mathrm{NaCl}$ solution in $3 \mathrm{mM}$ Tris$\mathrm{HCl}(\mathrm{pH} 7.4$ ), centrifuged at 10,000g for $1 \mathrm{~min}$ and solubilized in $200 \mu \mathrm{L}$ of the $0.9 \% \mathrm{NaCl}$-Tris buffer with $0.2 \%$ Triton X-100. A $100 \mu \mathrm{L}$ aliquot was added to $200 \mu \mathrm{L}$ of the Attophos reagent and allowed to react for $15 \mathrm{~min}$. at room temperature while protected from light. $200 \mu \mathrm{L}$ of this reacted solution were added to $96-$ well plates and the fluorescent intensity determined using a SPECTRAFluor Plus microplate reader with $430 \mathrm{~nm} / 595 \mathrm{~nm}$ excitation/emission filters. Calf intestinal ALP was included as an internal standard to normalize readings between experiments.

In order to determine the ALP activity/cell, cell density was also determined using the PicoGreen DNA quantification kit. The collected cell pellet was disrupted with $20 \mu \mathrm{L}$ of $0.1 \mathrm{~N}$ $\mathrm{NaOH}$ solution for 2 min. A $10 \mu \mathrm{L}$ aliquot was added to $90 \mu \mathrm{L}$ of $10 \mathrm{X}$ TE and $100 \mu \mathrm{L}$ of the PicoGreen reagent $(5 \mu \mathrm{L} / \mathrm{mL})$ and allowed to react for $5 \mathrm{~min}$ at room temperature while protected from light. $200 \mu \mathrm{L}$ of this reacted solution were added to 96-well plates and the fluorescent intensity determined using the microplate reader with $485 \mathrm{~nm} / 535 \mathrm{~nm}$ excitation/emission filters. A lambda standard was used as internal calibration.

\section{Alizarin Red-S Protocol for Mineralization}

The calcified mineral deposits were stained with Alizarin Red-S (AR-S) using the protocol developed by Gregory et al.[29] Briefly, separate 12-well plates after 8, 11, 15 and 24 days in culture were washed gently with PBS and fixed in 10\% (v:v) formaldehyde for 15 min. at room temperature. After washing twice with excess $\mathrm{dH}_{2} \mathrm{O}$, the samples were immersed in $0.5 \mathrm{~mL}$ of $40 \mathrm{mM}$ AR-S (pH 4.1) for $20 \mathrm{~min}$. with gentle shaking. Then, the samples were washed four times with excess $\mathrm{dH}_{2} \mathrm{O}$ for $5 \mathrm{~min}$. each with shaking. The wet samples were subsequently imaged by digital photography using an angled illumination source and stored at $-20^{\circ} \mathrm{C}$ prior to dye extraction. In order to quantify the amount of calcified mineral deposited on the samples, the following protocol was used to extract the AR-S dye. $800 \mathrm{uL}$ of $10 \%$ (v:v) acetic acid was 
Lee, MH; Adams, CS; Boettiger, D; DeGrado, WF; Shapiro, IM; Composto RJ; Ducheyne, P., 2007, Adhesion and function of MC3T3-E1 cells on RGD peptides of different flanking residues: Detachment strength and correlation with long-term cellular function, JOURNAL OF BIOMEDICAL MATERIALS RESEARCH, PT.A., IN PRESS.

added to the samples in 12-well plates and incubated for $30 \mathrm{~min}$. at room temperature with shaking. The cell monolayer was scraped off using a wide mouth pipette tip and the cell extract was transferred to centrifuge tubes and vortexed for $30 \mathrm{sec}$. The slurry was overlaid with $500 \mu \mathrm{L}$ of mineral oil at $85^{\circ} \mathrm{C}$ for $10 \mathrm{~min}$. After fully cooling in ice, the supernatant was discarded and $200 \mu \mathrm{L}$ of $10 \%(\mathrm{v}: \mathrm{v})$ ammonium hydroxide $(\mathrm{pH} \sim 4.1-4.5)$ was added to develop the color. 200 $\mu \mathrm{L}$ aliquots were added to 96-well plates and read at $405 \mathrm{~nm}$ using the microplate reader.

\section{Statistical Analysis}

Unless otherwise noted, the data are presented as averages $\pm 95 \%$ confidence intervals from three independent experiments done in triplicate $(n=9)$. One-way analysis of variance (ANOVA) was used to test for significance, at the $\mathrm{p}<0.05$ level. Pair-wise comparisons between substrate types were conducted using the Tukey-Kramer test at the same significance level.

\section{RESULTS}

\section{Development of the Peptide Immobilization Procedure}

Each step of the surface modification procedure was monitored using ellipsometry and water contact angle goniometry. The results are shown in Table 1. In all ellipsometric measurements, the underlying oxide $\left(\mathrm{SiO}_{2}\right)$ layer (thickness $\left.=1.4 \pm 0.0 \mathrm{~nm}\right)$ was subtracted. The thickness of the individual APTES, maleimide (BMPS) and acetyl (Ac) layers are $0.89 \pm 0.1 \mathrm{~nm}, 0.57 \pm 0.1$ $\mathrm{nm}$ and $0.19 \pm 0.1 \mathrm{~nm}$ respectively. The values of the APTES and BMPS layers correlate well with the theoretical estimates of $0.9 \mathrm{~nm},[30]$ and $0.69 \mathrm{~nm}$ respectively.[31] It should be noted that increasing the concentration and the reaction time for the crosslinker conjugation step did not significantly increase the thickness of the BMPS layer (data not shown). The water contact angle value of APTES is in agreement with reported range of value in the literature $[30,32]$ and the increase in hydrophobicity with the maleimide conjugation and acetylation are expected.

The detachment strength $\left(\tau_{50}\right)$ of MC3T3-E1 cells to substrates at each step of the modification procedure was also measured using the spinning disc apparatus and is shown in Fig. 2. The deposition of APTES onto $\mathrm{SiO}_{2}$ significantly increased $\tau_{50}$ to $453 \pm 20 \mathrm{dyne} / \mathrm{cm}^{2}(\mathrm{p}<0.01)$. The subsequent modification with BMPS, which reacts with the $\mathrm{NH}_{2}$ groups of APTES, reduced the 
Lee, MH; Adams, CS; Boettiger, D; DeGrado, WF; Shapiro, IM; Composto RJ; Ducheyne, P., 2007, Adhesion and function of MC3T3-E1 cells on RGD peptides of different flanking residues: Detachment strength and correlation with long-term cellular function, JOURNAL OF BIOMEDICAL MATERIALS RESEARCH, PT.A., IN PRESS.

$\tau_{50}$ to $230 \pm 16$ dyne $/ \mathrm{cm}^{2}(\mathrm{p}<0.01)$. Increasing the concentration and reaction time of the crosslinking step did not significantly reduce this value (data not shown). Acetylation of the remaining "free" $\mathrm{NH}_{2}$ groups, applying a protocol commonly used for $\mathrm{N}$-terminal modification of peptides, reduced the $\tau_{50}$ to $94 \pm 14$ dyne $/ \mathrm{cm}^{2}(\mathrm{p}<0.01)$. This value is not significantly different from that of the unmodified $\mathrm{SiO}_{2}$ substrate $\left(79 \pm 8\right.$ dyne/ $\left.\mathrm{cm}^{2}\right)$. Furthermore, this value is lower $(\mathrm{p}<0.05)$ than that achieved by coating the APTES with $1 \%$ heat-denatured bovine serum albumin solution ( 140 dyne $\left./ \mathrm{cm}^{2}\right)$, a commonly used procedure to minimize non-specific adhesion.

\section{Effect of RGD peptides on Cell Adhesion and Spreading}

Cellular adhesion to peptides immobilized on APTES-BMPS/Ac was quantitatively investigated with the modified substrates using the spinning disc assay. Fig. 3 shows the detachment strength of MC3T3-E1 cells to substrates modified with RGD peptides with different flanking residues. For these measurements, cells were seeded for $15 \mathrm{~min}$. (at $37{ }^{\circ} \mathrm{C}$ ) in order to isolate the initial attachment stage prior to spreading/flattening of the cell which have been shown to significantly alter measured $\tau_{50}$ values.[33] The $\tau_{50}$ values of the peptides are $214 \pm 15$ dyne $/ \mathrm{cm}^{2}, 339 \pm 46 \mathrm{dyne} / \mathrm{cm}^{2}$ and $229 \pm 7 \mathrm{dyne} / \mathrm{cm}^{2}$ for RGDS, RGDSPK and RGDSVVYGLR respectively. The adhesion mediated by RGDSPK is higher than those of RGDS and RGDSVVYGLR $(\mathrm{p}<0.05)$ which are not significantly different from each other. The $\tau_{50}$ values for all three RGD peptides are higher than the control RGES peptide $(\mathrm{p}<0.05)$ which has a value of $167 \pm 13 \mathrm{dyne} / \mathrm{cm}^{2}$.

The adhesion mediated by the different RGD peptides was also quantitatively compared to that of the Fn molecule in terms of detachment strength and integrin specificity. Figs. $4 \mathrm{a}$ and $4 \mathrm{~b}$ show the adhesion profiles from the spinning disc measurements for Fn and RGDS, respectively, with and without the addition of blocking anti- $\alpha_{5} \beta_{1}$ (BMA-5) and anti- $\alpha_{v}$ (RMV-7) monoclonal antibodies. The $\tau_{50}$ for Fn of equivalent surface density is $\sim 330$ dyne $/ \mathrm{cm}^{2}$ which is blocked by approximately two-third and one-third when BMA-5 and RMV-7 are added individually. When both $\mathrm{mAbs}$ are added, adhesion to Fn is reduced to $\sim 60$ dyne $/ \mathrm{cm}^{2}$. In contrast, the $\tau_{50}$ for RGDS is reduced to less than $90 \mathrm{dyne} / \mathrm{cm}^{2}$ (i.e. to that of the unmodified substrates) with the addition of RMV-7 alone. Addition of BMA-5 did not significantly lower the $\tau_{50}$ value for RGDS. 
Lee, MH; Adams, CS; Boettiger, D; DeGrado, WF; Shapiro, IM; Composto RJ; Ducheyne, P., 2007, Adhesion and function of MC3T3-E1 cells on RGD peptides of different flanking residues: Detachment strength and correlation with long-term cellular function, JOURNAL OF BIOMEDICAL MATERIALS RESEARCH, PT.A., IN PRESS.

Adhesion to RGDSPK and RGDSVVYGLR samples are also similarly blocked with RMV-7 but not significantly reduced by BMA-5 (data not shown). These results suggest that the MC3T3-E1 adhesion to RGD peptides are primarily $\alpha_{\mathrm{v}} \beta_{3}-\alpha_{\mathrm{v}} \beta_{5}$-mediated whereas the adhesion to Fn occurs through significant interaction with both the $\alpha_{5} \beta_{1}$ and $\alpha_{v}$ integrins expressed by these cells. The presence of $\alpha_{5} \beta_{1}$ and $\alpha_{\mathrm{v}}$ integrins on the surface of MC3T3-E1 cells was verified by flow cytometry using BMA-5 and RMV-7 mAbs respectively (data not shown).

The spreading of MC3T3-E1 cells were qualitatively observed by fluorescence microscopy at $15 \mathrm{~min} ., 1 \mathrm{~h}, 2.5 \mathrm{~h}$ and $5 \mathrm{~h}$. The spreading areas for the substrates were quantified for 5-10 20x images and are shown as Fig. 5. At $15 \mathrm{~min}$., the cell area is not significantly different for all substrates. However, after $1 \mathrm{~h}, 2.5 \mathrm{~h}$ and $5 \mathrm{~h}$, the cell area on the RGD surfaces is significantly higher than on the control RGES and BMPS-OH surfaces ( $p<0.05$ ). The differences between the three RGDS peptides are not significant at all times. It should be noted that BMPS-OH represents a neutral maleimide-functional substrate which does not possess any peptide but was similarly modified with the $\beta \mathrm{ME}$ blocking step as the peptide samples.

\section{Alkaline phosphatase activity}

Fluorescence measurements of ALP activity of MC3T3-E1 cells cultured on the peptide modified surfaces after 8,11 and 15 days were normalized to cell number and are shown in Fig. 6. The differentiation and mineralization pattern of this cell line has been well-characterized previously by others.[34-37] ALP activity level gradually increases to significant values after 815 days in culture for all samples tested. The most significant effect is observed with the RGDSPK surfaces with which the ALP activity increases from day 8 to day $11(\mathrm{p}<0.05)$ and then decreases by day 15. This trend is qualitatively similar to that of Fn. In contrast, the maximal ALP levels for RGDS and RGDSVVYGLR are observed after 15 days. With the exception of RGDSVVYGLR at day 11, the ALP activities of all three peptides are higher than those of the BMPS-OH and RGES controls at days 11 and $15(\mathrm{p}<0.05)$. It should be noted that the ALP activity of the MC3T3-E1 cells used in the study was generally low which may indicate the presence of some phenotypic drift in the cell line. Nevertheless, attachment to the RGD peptides and fibronectin elicited significant increases over the controls and suggests that the appropriate integrin-mediated signaling has occurred. 
Lee, MH; Adams, CS; Boettiger, D; DeGrado, WF; Shapiro, IM; Composto RJ; Ducheyne, P., 2007, Adhesion and function of MC3T3-E1 cells on RGD peptides of different flanking residues: Detachment strength and correlation with long-term cellular function, JOURNAL OF BIOMEDICAL MATERIALS RESEARCH, PT.A., IN PRESS.

\section{Mineralization}

The deposition of a calcified mineralized matrix by the MC3T3-E1 cells was qualitatively monitored using a digital camera after 11,15 and 24 days. Using the protocol of Gregory et al.,[29] the alizarin red-S stain on the samples was extracted and assayed to quantify the mineral content on the samples. Figs. 7 and. 8 show representative digital images and the absorbance of the extracted alizarin dye for the samples respectively. The images for the BMPS-OH samples are not included because they are similar in appearance to the RGES control. Mineralization is not observed after 11 days for all peptide substrates. Some mineral nodules are present on the RGDS and RGDSPK samples after 15 days in culture and all peptide-modified substrates show large mineralized areas after 24 days. Fig. 8 shows that the trend in mineralized matrix after 15 days is $\mathrm{RGDSPK} \approx \mathrm{RGDS}>\mathrm{RGDSVVYGLR}>\mathrm{RGES} \approx \mathrm{BMPS}-\mathrm{OH}(\mathrm{p}<0.05)$. Mineralization on Fn is significantly higher than that on the peptide substrates at this time point, however after 24 days, RGDS and RGDSPK samples are not significantly different from Fn $(\mathrm{p}<0.05)$. The three RGD peptides show larger amount of mineralization than the RGES and BMPS-OH controls at 15 and 24 days $(\mathrm{p}<0.05)$.

\section{DISCUSSION}

In previous studies, we demonstrated that RGD immobilized via APTES on a deformable poly(dimethylsiloxane) (PDMS) membrane[2] and on a silicon substrate[3] enhances the adhesion and function of MC3T3-E1 and rat osteosarcoma (ROS) cells respectively. The minimum RGD tri-peptide sequence was shown to cause a dramatic difference in $\alpha_{\mathrm{v}} \beta_{3}$ integrin distribution at focal contacts after $6 \mathrm{~h}$ and significant increases in the expression of $\beta_{3}, \beta_{1}$ and $\alpha_{\mathrm{v}}$ subunits and of osteoblast-specific genes (osteocalcin, osteopontin and bone sialoprotein) after 34 days. After 8-12 days, significant increases in ALP activity and mineral deposition were observed on the RGD modified PDMS surfaces. The current study expands upon these earlier studies by quantitatively investigating the role of the residues flanking the RGD on osteoblast adhesion and its correlation with long-term cellular function. 
Lee, MH; Adams, CS; Boettiger, D; DeGrado, WF; Shapiro, IM; Composto RJ; Ducheyne, P., 2007, Adhesion and function of MC3T3-E1 cells on RGD peptides of different flanking residues: Detachment strength and correlation with long-term cellular function, JOURNAL OF BIOMEDICAL MATERIALS RESEARCH, PT.A., IN PRESS.

First, a conjugate chemistry was developed to attach RGD peptides to $\mathrm{SiO}_{2}$ and the level of non-specific cellular adhesion was verified using the spinning disc apparatus. As we had previously demonstrated with an erythroleukemia cell line (K100), electrostatic interactions play a particularly important role in the adhesion of cells to amine-functional substrates.[7] The magnitude of the non-specific adhesion of MC3T3-E1 cells to the APTES SAM was even larger $(\sim 2.5 \mathrm{x})$ than that previously reported for K100 cells. The difference between the two cell types is likely to be caused by differences in the composition and charge of the membranes [38] and not by differences in cell spreading/flattening (verified by SEM - data not shown). Reacting APTES with the maleimide crosslinker reduced the $\tau_{50}$ value of APTES, however approximately $50 \%$ of the non-specific effect remained. Since neither increasing the concentration of the crosslinker solution nor the reaction time altered this value, the results suggest that the large disparity in the sizes of the densely packed amine functional groups of APTES and the crosslinker molecules hinders completion of the crosslinking reaction. Addition of an acetylation step was necessary to further reduce the non-specific interaction to that of the unmodified $\mathrm{SiO}_{2}$ controls.

A series of RGD peptides were synthesized and characterized for this work. Besides the different cell binding domains, all peptides possessed additional components: (1) Cys for specific conjugation to maleimide groups, (2) Tyr for accurate quantification of peptide concentrations in solution (UV Absorption) and on the surface (Radiolabeling), (3) an acetylated N-terminal $\mathrm{NH}_{2}$ on the peptides to eliminate potential background adhesion, and (4) a Gly-Gly spacer to separate these functional domains from the cell binding sequence. The modular peptide design used herein eliminates two of the main problems in previous studies using RGD peptides. Namely, these include ambiguity in the mode of attachment and the lack of direct quantification of surface density. The combination of the peptide design and the modified maleimide substrate allowed assessment of the detachment strength of MC3T3-E1 cells to RGD peptides of differing flanking residues: RGDSPK $>>$ RGDSVVYGLR $\approx$ RGDS $>$ RGES. The trend suggests that higher affinity peptides generally result in higher cellular detachment strength. In comparing RGDSPK and RGDSVVYGLR closely however, it is apparent that the role of affinity in determining the detachment strength is more complex. Based on simple solution-phase or inhibition assay $\left(\mathrm{IC}_{50}\right)$ measurements of the affinity of the peptide for the $\alpha_{v} \beta_{3}$ integrin, the $\mathrm{K}_{\mathrm{D}}^{-1}$ values of 
Lee, MH; Adams, CS; Boettiger, D; DeGrado, WF; Shapiro, IM; Composto RJ; Ducheyne, P., 2007, Adhesion and function of MC3T3-E1 cells on RGD peptides of different flanking residues: Detachment strength and correlation with long-term cellular function, JOURNAL OF BIOMEDICAL MATERIALS RESEARCH, PT.A., IN PRESS.

RGDSVVYGLR and RGDSPK are expected to be similar orders of magnitude $\left(\sim 10^{0}-10^{1}\right.$ $\mu \mathrm{M}$ ).[13] Therefore, other factors are likely to play a significant role in the higher detachment strength measured for RGDSPK. In the context of the results of Fig. 2, it is likely that the lysine residue of RGDSPK also enhances cellular adhesion through a non-specific mechanism. Although this interaction does not directly affect integrin binding, incorporation of additional Lys residues may provide a useful method to increase the ability of weak RGD peptides to support cellular adhesion.

Since RGD-containing peptides and proteins are generally capable of interacting with multiple integrins, the adhesion mediated by the RGD peptides and by adsorbed Fn adsorbed were compared on the basis of detachment strength and integrin specificity. Fn represents a native state in which peptides such as RGD and (G)RGDSP exist and is a standard against which the activity of these peptides can be compared. At surface densities equivalent to that of the RGD peptides, the specific contribution of Fn-mediated adhesion is approximately $300 \mathrm{dynes} / \mathrm{cm}^{2}$. This is more than six times greater than the difference in $\tau_{50}$ values between RGDS and RGES. It is not clear at this time whether the greater detachment strengths for Fn are due to stronger bonds formed with $\alpha_{5} \beta_{1}$ integrins or simply a greater number of total bonds with both integrin types. By using adhesion blocking mAbs against $\alpha_{5} \beta_{1}$ and $\alpha_{v}$ integrins, the difference between the peptide and Fn-mediated adhesion was further clarified. Whereas the adhesion of MC3T3E1 cells to Fn was mediated by significant interactions with both the $\alpha_{5} \beta_{1}$ and $\alpha_{v}$ integrins (i.e. $\alpha_{v} \beta_{3}$ and $\alpha_{v} \beta_{5}$ ), the specific adhesion of cells to all RGD peptides was abolished when $\alpha_{v}$ integrins were blocked. These findings demonstrate that there are significant differences in the initial interactions mediated by RGD peptides vs. Fn with the integrins of MC3T3-E1 cells.

In tissue engineering applications, the purpose of using RGD peptide-immobilized substrates is to support cell function beyond adhesion. In order to test whether differences in adhesion among RGD peptides and Fn also resulted in long-term phenotypic changes, cell spreading, ALP activity and mineralization of MC3T3-E1 cells were also evaluated. Measurements of cell area showed that spreading on the three RGD peptides and Fn were greatly enhanced in comparison to the controls after 15 min. However, a significant difference between the three RGD peptides 
Lee, MH; Adams, CS; Boettiger, D; DeGrado, WF; Shapiro, IM; Composto RJ; Ducheyne, P., 2007, Adhesion and function of MC3T3-E1 cells on RGD peptides of different flanking residues: Detachment strength and correlation with long-term cellular function, JOURNAL OF BIOMEDICAL MATERIALS RESEARCH, PT.A., IN PRESS.

of different flanking residues was not found. The results suggest that small changes in the residues flanking the RGD sequence are not sufficient to cause changes in cell spreading. Alternatively, the lack of a correlation in spreading with the trend in $\tau_{50}$ values may be due to greater variation in the spreading assay as well.

When the ALP activity and deposition of the mineralized matrix were evaluated, the general trend found in these assays correlated well with that of the adhesion measurements. RGDSPK was the most effective peptide with a peak in ALP activity after 11 days; it reached a similar level as Fn but in a longer time period. In comparison, maximum values for RGDS and RGDSVVYGLR occurred later, after 15 days, and suggested that differentiation with these peptides were either delayed, possibly due to lower initial cell densities (as suggested by the lower detachment strengths), or that the effect of these peptides on ALP activity was lower. The mineralization results were similar and supported this interpretation. The amount of calcified mineral on RGDSPK and RGDS were significantly greater than RGDSVVYGLR after 15 days. By 24 days in culture, mineralization on these two RGD peptides was similar to the level on Fn. Although further characterization of the minerals by techniques such as X-ray diffraction and FTIR was not possible on these samples, previous work has shown that the mineral formed by these cells with analogous samples under similar culture conditions is a biological apatite.[2] It should also be noted that in the spreading, ALP and ARS assays, a hydroxyl-terminated SAM (OH SAM) saturated with adsorbed Fn was used as a positive control because this substrate has been shown to enhance $\alpha_{5} \beta_{1}$ integrin-mediated cellular adhesion[39] and mineral deposition by MC3T3-E1 cells.[40] Therefore, the results for Fn, reported in the present study, represent the maximum bioactivity that can be obtained by modulation of the biomaterial surface chemistry alone.

In summary, the effect of altering the residues flanking the RGD peptide sequence has an immediate effect on adhesion causing subtle changes in both osteoblast differentiation and mineralization. However, despite a lower ligand surface density, fibronectin was generally more effective than the RGD peptides. This finding lends strength to the notion that motifs other than the RGD cell-binding domain, are important functional components of the protein. It has also 
Lee, MH; Adams, CS; Boettiger, D; DeGrado, WF; Shapiro, IM; Composto RJ; Ducheyne, P., 2007, Adhesion and function of MC3T3-E1 cells on RGD peptides of different flanking residues: Detachment strength and correlation with long-term cellular function, JOURNAL OF BIOMEDICAL MATERIALS RESEARCH, PT.A., IN PRESS.

been suggested recently that $\alpha_{5} \beta_{1}$ integrins may play a larger role than $\alpha_{v} \beta_{3}$ integrins in transducing the osteogenic activities of MC3T3-E1 cells.[41,42] Despite interacting primarily with $\alpha_{v}$ integrins, RGDSPK-modified substrates were nearly as effective as Fn at longer culture times. This finding suggests that it is possible to enhance the osteogenic activity of RGD by both 1) grafting of the peptides to the material at a higher surface density than achievable by simple adsorption of Fn and 2) optimization of peptide design. With respect to the short, linear RGD peptides, we show that the weak inherent activity can be increased by the inclusion of a Lys residue to the peptide. Although these residues are not likely to participate directly in integrin binding, they may indirectly increase cell function by enhancing the mechanical stability of adherent cells on the biomaterial surface.

\section{CONCLUSION}

The novel immobilization strategy described in this work represents a versatile platform on which to evaluate the effect of peptides and proteins on cellular adhesion and function with minimal contribution from non-specific interactions. Using these substrates, the residues flanking the RGD sequence in peptides was shown to significantly influence the adhesion and long-term function of MC3T3-E1 cells. In contrast to the full Fn molecule which interacted significantly with both $\alpha_{5} \beta_{1}$ and $\alpha_{\mathrm{v}}$ integrins, cellular adhesion to all RGD peptides was $\alpha_{\mathrm{v}}-$ mediated and weaker at equivalent surface densities. Surprisingly, the incorporation of a lysine residue in RGDSPK, significantly influenced osteoblast adhesion. Importantly, over $5 \mathrm{~h}$, the peptides exerted a similar trend in alkaline phosphatase activity and mineral deposition as the adhesion status. These findings quantitatively demonstrate both the possibilities and limitations of enhancing the osteogenic response of RGD-immobilized biomaterials by changes in peptide design.

The authors would like to thank Drs. Zelleka Getahun and Gaston Vilaire for their assistance with peptide synthesis and radiolabeled experiments respectively. The authors would also like to acknowledge Gabriela A. Silva for her assistance with the osteoblast cell function assays. This 
Lee, MH; Adams, CS; Boettiger, D; DeGrado, WF; Shapiro, IM; Composto RJ; Ducheyne, P., 2007, Adhesion and function of MC3T3-E1 cells on RGD peptides of different flanking residues: Detachment strength and correlation with long-term cellular function, JOURNAL OF BIOMEDICAL MATERIALS RESEARCH, PT.A., IN PRESS.

research was supported by NIH (Ro1 DE-13009), Department of Defense (DAMD 17-03-10713, PRMRP) and an Interdisciplinary Seed Grant from the Institute for Medicine and Engineering (Univ. of PA). 
Lee, MH; Adams, CS; Boettiger, D; DeGrado, WF; Shapiro, IM; Composto RJ; Ducheyne, P., 2007, Adhesion and function of MC3T3-E1 cells on RGD peptides of different flanking residues: Detachment strength and correlation with long-term cellular function, JOURNAL OF BIOMEDICAL MATERIALS RESEARCH, PT.A., IN PRESS.

\section{REFERENCES}

[1] Hynes RO. Integrins: versatility, modulation, and signaling in cell adhesion. Cell 1992;69:11-25.

[2] Cavalcanti-Adam EA, Shapiro IM, Composto RJ, Macarak EJ, Adams CS. RGD peptides immobilized on a mechanically deformable surface promote osteoblast differentiation. J Bone Miner Res 2002;17:2130-2140.

[3] El Ghannam AR, Ducheyne P, Risbud M, Adams CS, Shapiro IM, Castner D, Golledge $\mathrm{S}$, Composto RJ. Model surfaces engineered with nanoscale roughness and RGD tripeptides promote osteoblast activity. J Biomed Mater Res, Pt A 2004;68A:615-627.

[4] Dee KC, Rueger DC, Andersen TT, Bizios R. Conditions which promote mineralization at the bone-implant interface: a model in vitro study. Biomat 1996;17:209-215.

[5] Rezania A, Healy KE. Biomimetic Peptide Surfaces That Regulate Adhesion, Spreading, Cytoskeletal Organization, and Mineralization of the Matrix Deposited by Osteoblast-like Cells. Biotechnol Prog 1999;15:19-32.

[6] Mrksich M. Using self-assembled monolayers to understand the biomaterials interface. Curr Opin Coll Interface Sci 1997;2:83-88.

[7] Lee MH, Brass DA, Morris R, Composto RJ, Ducheyne P. The effect of non-specific interactions on cellular adhesion using model surfaces. Biomat 2005;26:1721-1730.

[8] Xiao SJ, Textor M, Spencer ND, Wieland M, Keller B, Sigrist H. Immobilization of the cell-adhesive peptide Arg-Gly-Asp-Cys (RGDC) on titanium surfaces by covalent chemical attachment. J Mater Sci: Mater Med 1997;8:867-872.

[9] Rezania A, Johnson R, Lefkow AR, Healy KE. Bioactivation of Metal Oxide Surfaces. 1. Surface Characterization and Cell Response. Langmuir 1999;15:6931-6939.

[10] Gronowicz GA, Derome ME. Synthetic peptide containing Arg-Gly-Asp inhibits bone formation and resorption in a mineralizing organ culture system of fetal rat parietal bones. J Bone Miner Res 1994;9:193-201.

[11] Cowles EA, Brailey LL, Gronowicz GA. Integrin-mediated signaling regulates AP-1 transcription factors and proliferation in osteoblasts. J Biomed Mater Res 2000;52:725737.

[12] Dettin M, Conconi MT, Gambaretto R, Pasquato A, Folin M, Di Bello C et al. Novel osteoblast-adhesive peptides for dental/orthopedic biomaterials. J Biomed Mater Res 2002;60:466-471. 
Lee, MH; Adams, CS; Boettiger, D; DeGrado, WF; Shapiro, IM; Composto RJ; Ducheyne, P., 2007, Adhesion and function of MC3T3-E1 cells on RGD peptides of different flanking residues: Detachment strength and correlation with long-term cellular function, JOURNAL OF BIOMEDICAL MATERIALS RESEARCH, PT.A., IN PRESS.

[13] Helluin O, Chan C, Vilaire G, Mousa S, DeGrado WF, Bennett JS. The activation state of avb3 regulates platelet and lymphocyte adhesion to intact and thrombin-cleaved osteopontin. J Biol Chem 2000;275:18337-18343.

[14] Pistone M, Sanguineti C, Federici A, Sanguineti F, Defilippi P, Santolini F et al. Integrin synthesis and utilization in cultured human osteoblasts. Cell Biol Int 1996;20:471-479.

[15] Moursi AM, Globus RK, Damsky CH. Interactions between integrin receptors and fibronectin are required for calvarial osteoblast differentiation in vitro. J Cell Sci 1997;110 (Pt 18):2187-2196.

[16] Gronthos S, Stewart K, Graves SE, Hay S, Simmons PJ. Integrin expression and function on human osteoblast-like cells. J Bone Miner Res 1997;12:1189-1197.

[17] Lee MH, Ducheyne P, Lynch L, Boettiger D, Composto Russell J. Effect of biomaterial surface properties on fibronectin-alpha5beta1 integrin interaction and cellular attachment. Biomat 2006;27:1907-1916.

[18] Xiao SJ, Textor M, Spencer ND, Sigrist H. Covalent Attachment of Cell-Adhesive, (ArgGly-Asp)-Containing Peptides to Titanium Surfaces. Langmuir 1998;14:5507-5516.

[19] Ulman A. An Introduction to Ultrathin Organic Films: From Langmuir-Blodgett to SelfAssembly. Boston: Academic Press; 1991.

[20] Fmoc solid phase peptide synthesis : a practical approach. Oxford: Oxford University Press; 2000.

[21] Garcia AJ, Huber F, Boettiger D. Force required to break a5b1 integrin-fibronectin bonds in intact adherent cells is sensitive to integrin activation state. J Biol Chem 1998;273:10988-10993.

[22] Chung CY, Iida-Klein A, Wyatt LE, Rudkin GH, Ishida K, Yamaguchi DT et al. Serial passage of MC3T3-E1 cells alters osteoblastic function and responsiveness to transforming growth factor-betal and bone morphogenetic protein-2. Biochem Biophys Res Commun 1999;265:246-251.

[23] Garcia AJ, Ducheyne P, Boettiger D. Quantification of cell adhesion using a spinning disk device and application to surface-reactive materials. Biomat 1997;18:1091-1098.

[24] Takahashi K, Nakamura T, Koyanagi M, Kato K, Hashimoto Y, Yagita H et al. A murine very late activation antigen-like extracellular matrix receptor involved in CD2- and lymphocyte function-associated antigen-1-independent killer-target cell interaction. J Immunol 1990;145:4371-4379.

[25] Narumiya S, Abe Y, Kita Y, Miyake K, Nakajima K, Watanabe TX et al. Pre-B cells adhere to fibronectin via interactions of integrin alpha 5/alpha V with RGDS as well as of 
Lee, MH; Adams, CS; Boettiger, D; DeGrado, WF; Shapiro, IM; Composto RJ; Ducheyne, P., 2007, Adhesion and function of MC3T3-E1 cells on RGD peptides of different flanking residues: Detachment strength and correlation with long-term cellular function, JOURNAL OF BIOMEDICAL MATERIALS RESEARCH, PT.A., IN PRESS.

integrin alpha 4 with two distinct $\mathrm{V}$ region sequences at its different binding sites. Int Immunol 1994;6:139-147.

[26] Piali L, Hammel P, Uherek C, Bachmann F, Gisler RH, Dunon D et al. CD31/PECAM-1 is a ligand for alpha $v$ beta 3 integrin involved in adhesion of leukocytes to endothelium. J Cell Biol 1995;130:451-460.

[27] Fehlner-Gardiner CC, Uniyal S, von Ballestrem CG, Chan BM. Differential utilization of VLA-4 (alpha 4 beta 1) and -5 (alpha 5 beta 1) integrins during the development of mouse bone marrow-derived mast cells. Differentiation 1996;60:317-325.

[28] Uniyal S, Boeters L, Chakrabarti S, Singh B, Chan BMC. Leukocytes Utilize Both [alpha]4 and[alpha]5 Integrins for Intraislet Infiltration in Non-obese Diabetic Mice. J Autoimm 1999;12:167-176.

[29] Gregory CA, Gunn WG, Peister A, Prockop DJ. An Alizarin red-based assay of mineralization by adherent cells in culture: comparison with cetylpyridinium chloride extraction. Anal Biochem 2004;329:77-84.

[30] Petri DFS, Wenz G, Schunk P, Schimmel T. An Improved Method for the Assembly of Amino-Terminated Monolayers on $\mathrm{SiO} 2$ and the Vapor Deposition of Gold Layers. Langmuir 1999;15:4520-4523.

[31] Pierce Biotechnology. Double-Agents(TM) Handbook. 2003.

[32] Heiney PA, Grueneberg K, Fang J, Dulcey C, Shashidhar R. Structure and Growth of Chromophore-Functionalized (3-Aminopropyl)triethoxysilane Self-Assembled on Silicon. Langmuir 2000;16:2651-2657.

[33] Truskey GA, Pirone JS. The effect of fluid shear stress upon cell adhesion to fibronectintreated surfaces. J Biomed Mat Res 1990;24:1333-1353.

[34] Sudo H, Kodama HA, Amagai Y, Yamamoto S, Kasai S. In vitro differentiation and calcification in a new clonal osteogenic cell line derived from newborn mouse calvaria. J Cell Biol 1983;96:191-198.

[35] Choi JY, Lee BH, Song KB, Park RW, Kim IS, Sohn KY et al. Expression patterns of bone-related proteins during osteoblastic differentiation in MC3T3-E1 cells. J Cell Biochem 1996;61:609-618.

[36] Beck GR, Jr., Sullivan EC, Moran E, Zerler B. Relationship between alkaline phosphatase levels, osteopontin expression, and mineralization in differentiating MC3T3E1 osteoblasts. J Cell Biochem 1998;68:269-280.

[37] Wang D, Christensen K, Chawla K, Xiao G, Krebsbach PH, Franceschi RT. Isolation and characterization of MC3T3-E1 preosteoblast subclones with distinct in vitro and in vivo differentiation/mineralization potential. J Bone Miner Res 1999;14:893-903. 
Lee, MH; Adams, CS; Boettiger, D; DeGrado, WF; Shapiro, IM; Composto RJ; Ducheyne, P., 2007, Adhesion and function of MC3T3-E1 cells on RGD peptides of different flanking residues: Detachment strength and correlation with long-term cellular function, JOURNAL OF BIOMEDICAL MATERIALS RESEARCH, PT.A., IN PRESS.

[38] Van Damme MP, Tiglias J, Nemat N, Preston BN. Determination of the charge content at the surface of cells using a colloid titration technique. Anal Biochem 1994;223:62-70.

[39] Keselowsky BG, Collard DM, Garcia AJ. Surface chemistry modulates fibronectin conformation and directs integrin binding and specificity to control cell adhesion. $\mathrm{J}$ Biomed Mater Res, Pt A 2003;66A:247-259.

[40] Keselowsky BG, Collard DM, Garcia AJ. Surface chemistry modulates focal adhesion composition and signaling through changes in integrin binding. Biomat 2004;25:59475954.

[41] Cheng SL, Lai CF, Blystone SD, Avioli LV. Bone mineralization and osteoblast differentiation are negatively modulated by integrin alpha(v)beta3. J Bone Miner Res 2001;16:277-288.

[42] Keselowsky BG, Collard DM, Garcia AJ. Integrin binding specificity regulates biomaterial surface chemistry effects on cell differentiation. Proc Natl Acad Sci USA 2005;102:5953-5957. 
Lee, MH; Adams, CS; Boettiger, D; DeGrado, WF; Shapiro, IM; Composto RJ; Ducheyne, P., 2007, Adhesion and function of MC3T3-E1 cells on RGD peptides of different flanking residues: Detachment strength and correlation with long-term cellular function, JOURNAL OF BIOMEDICAL MATERIALS RESEARCH, PT.A., IN PRESS.

Table 1. Ellipsometric Thickness, sessile-drop water contact angle and the detachment strength of MC3T3-E1 cells on substrates at various levels of surface modification. The detachment strengths were measured using the spinning disc apparatus after allowing the cells to adhere for 15 min at $37^{\circ} \mathrm{C}$ in DMEM. The changes in thickness and hydrophobicity verified each step of the modification procedure. The detachment strength of the final substrate on which the peptides were immobilized (APTES-BMPS/Ac) was not statistically different than unmodified $\mathrm{SiO}_{2}$. All values are mean $\pm 95 \%$ Confidence Interval.

\begin{tabular}{|c|c|c|c|}
\hline Substrate & Thickness (nm) & $\begin{array}{c}\text { Contact Angle } \\
\left({ }^{\circ}, \text { Water }\right)\end{array}$ & $\begin{array}{c}\text { Detachment Strength, } \\
\tau_{50}\left(\text { dyne } / \mathrm{cm}^{2}\right)\end{array}$ \\
\hline $\mathrm{SiO} 2$ & - & 0 & $79 \pm 8$ \\
\hline APTES & $0.89 \pm 0.1$ & $41.6 \pm 2.8$ & $453 \pm 20$ \\
\hline APTES-BMPS & $1.46 \pm 0.1$ & $46.5 \pm 1.4$ & $230 \pm 16$ \\
\hline APTES-BMPS/Ac & $1.65 \pm 0.1$ & $52.3 \pm 2.7$ & $94 \pm 14$ \\
\hline
\end{tabular}


Lee, MH; Adams, CS; Boettiger, D; DeGrado, WF; Shapiro, IM; Composto RJ; Ducheyne, P., 2007, Adhesion and function of MC3T3-E1 cells on RGD peptides of different flanking residues: Detachment strength and correlation with long-term cellular function, JOURNAL OF BIOMEDICAL MATERIALS RESEARCH, PT.A., IN PRESS.

Figure 1. Representative detachment profiles of two substrates of different adhesiveness from the spinning disc apparatus. Three representative microscopic images (10x) of the attached cells at the center, at an intermediate radius and at the edge of the disc are shown as inserts. The solid lines are sigmoidal fits to the data which are used to determine the $\tau_{50}$ values.

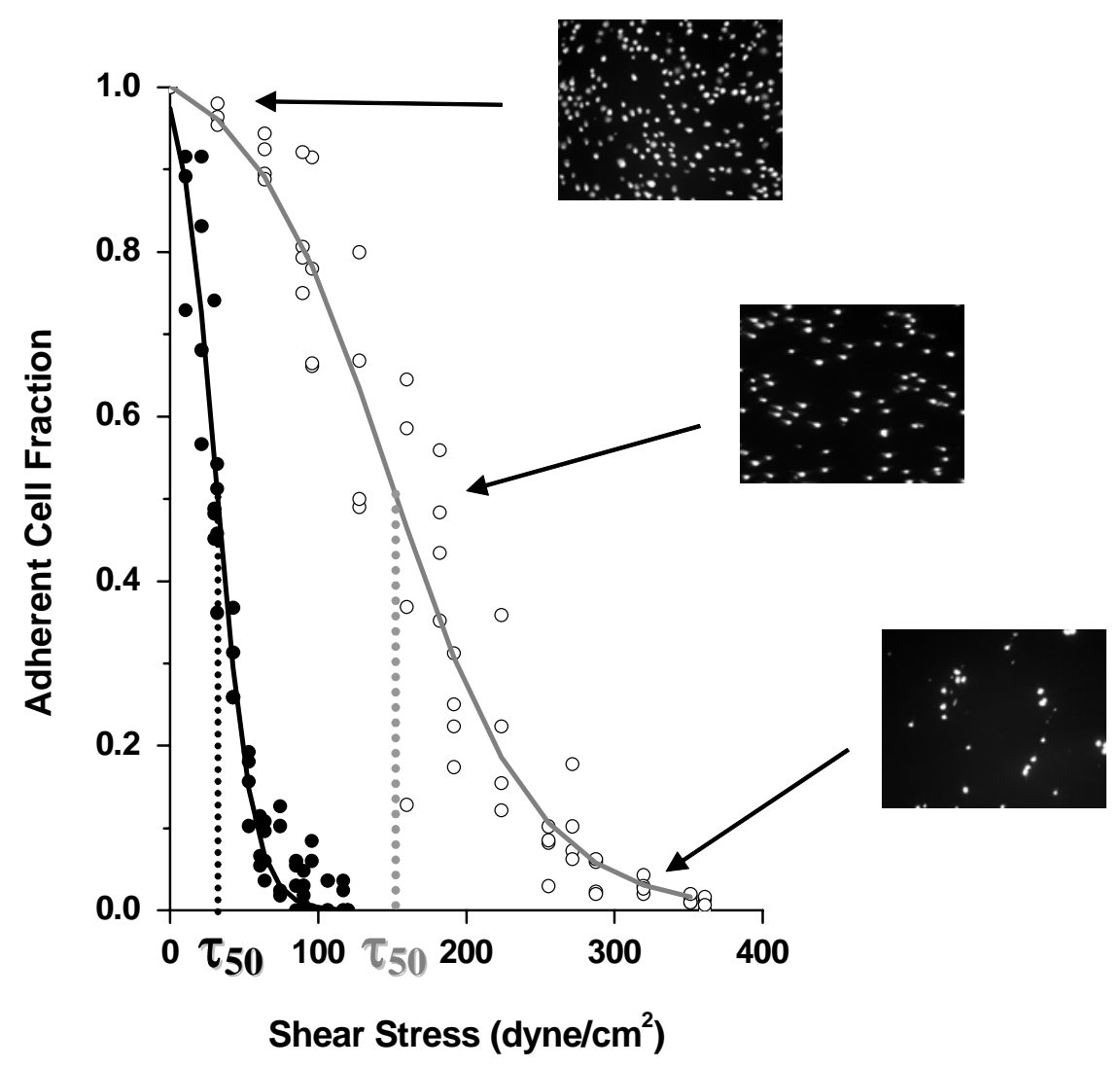


Lee, MH; Adams, CS; Boettiger, D; DeGrado, WF; Shapiro, IM; Composto RJ; Ducheyne, P., 2007, Adhesion and function of MC3T3-E1 cells on RGD peptides of different flanking residues: Detachment strength and correlation with long-term cellular function, JOURNAL OF BIOMEDICAL MATERIALS RESEARCH, PT.A., IN PRESS.

Figure 2. A schematic of the novel peptide attachment strategy used to minimize non-specific cellular adhesion. Addition of the acetylation procedure to the BMPS modified APTES substrate (APT-BMPS) significantly lowered the detachment strength of MC3T3-E1 cells, in comparison to APT-BMPS without acetylation $(\mathrm{p}<0.01)$. The detachment strength was measured after the cells were allowed to attach for $15 \mathrm{~min}$. at $37^{\circ} \mathrm{C}$ in DMEM. Bars are means $\pm 95 \%$ Confidence Intervals $(\mathrm{n}=10)$.

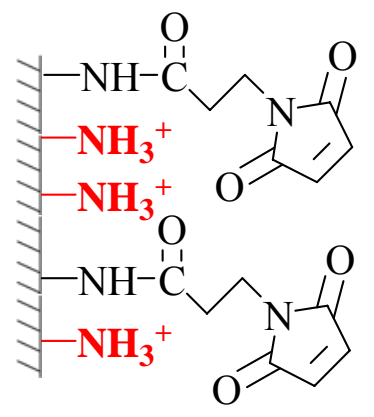

APT-BMPS

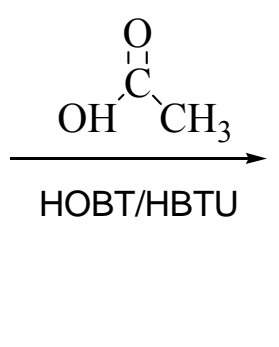

APT-BMPS/Ac

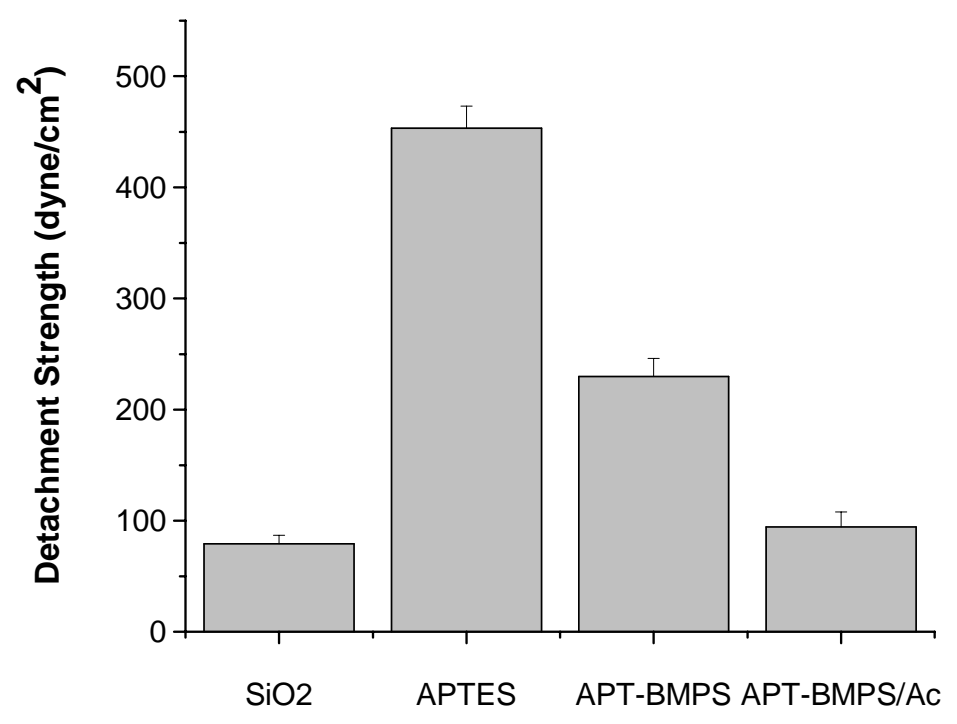

Corresponding author; E-mail address: markhl@alumni.upenn.edu 
Lee, MH; Adams, CS; Boettiger, D; DeGrado, WF; Shapiro, IM; Composto RJ; Ducheyne, P., 2007, Adhesion and function of MC3T3-E1 cells on RGD peptides of different flanking residues: Detachment strength and correlation with long-term cellular function, JOURNAL OF BIOMEDICAL MATERIALS RESEARCH, PT.A., IN PRESS.

Figure 3. Detachment strength of MC3T3-E1 cells to peptide-modified APT-BMPS/Ac substrates after 15 min. attachment at $37^{\circ} \mathrm{C}$ in DMEM. The detachment strengths of cells to all three RGDS-containing peptides were higher than to the RGES control. In pair-wise comparisons between RGDS-containing peptides, RGDSPK was significantly higher than both RGDS and RGDSVVYGLR $(\mathrm{p}<0.05)$. Bars are means $\pm 95 \%$ Confidence Intervals $(\mathrm{n}=10)$.

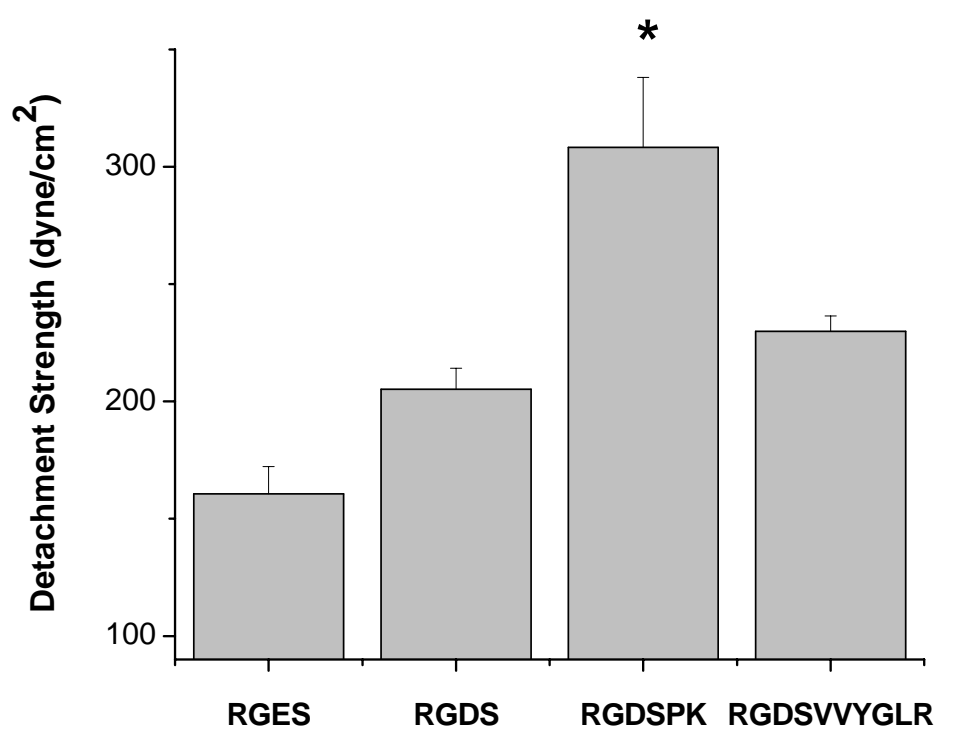


Lee, MH; Adams, CS; Boettiger, D; DeGrado, WF; Shapiro, IM; Composto RJ; Ducheyne, P., 2007, Adhesion and function of MC3T3-E1 cells on RGD peptides of different flanking residues: Detachment strength and correlation with long-term cellular function, JOURNAL OF BIOMEDICAL MATERIALS RESEARCH, PT.A., IN PRESS.

Figure 4a. Detachment strength of MC3T3-E1 cells to silicon substrates coated with $10 \mu \mathrm{g} / \mathrm{mL}$ of Fn and subsequently blocked with $1 \%$ heat-denatured BSA. The cells were allowed to adhere for 15 min. at $37^{\circ} \mathrm{C}$ in DMEM with the addition of: (1) no mAbs (•), (2) BMA-5, (3) RMV-7 and (4) both mAbs ( $\boldsymbol{\Xi})$ prior to detachment. The addition of BMA-5 decreased the $\tau_{50}$ value by twice the magnitude as adding RMV-7 which suggests that MC3T3-E1 adhesion to Fn is dominated by interactions with $\alpha_{5} \beta_{1}$ integrins. The data points for the samples with BMA-5 and RMV-7 are omitted for clarity.

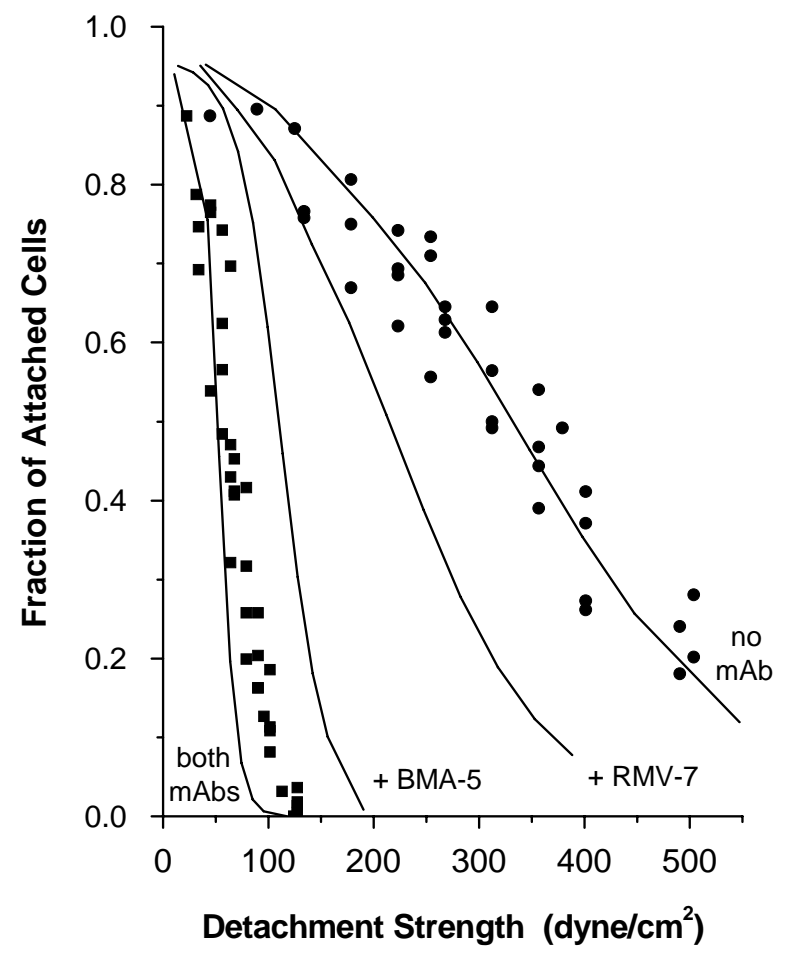


Lee, MH; Adams, CS; Boettiger, D; DeGrado, WF; Shapiro, IM; Composto RJ; Ducheyne, P., 2007, Adhesion and function of MC3T3-E1 cells on RGD peptides of different flanking residues: Detachment strength and correlation with long-term cellular function, JOURNAL OF BIOMEDICAL MATERIALS RESEARCH, PT.A., IN PRESS.

Figure 4b. Detachment strength of MC3T3-E1 cells to RGDSVVYGLR-immobilized substrate. The cells were allowed to adhere for $15 \mathrm{~min}$. at $37^{\circ} \mathrm{C}$ in DMEM prior to detachment. The cells were seeded with the addition of: (1) no mAbs (•), (2) BMA-5 and (3) RMV-7 (घ). The addition of RMV-7 decreased the $\tau_{50}$ value to near background levels ( $\sim 94$ dynes $\left./ \mathrm{cm}^{2}\right)$ while adding BMA-5 produced little effect. The detachment strengths of cells to RGDS and RGDSPK-immobilized substrates were blocked similarly with the addition of BMA-5 or RMV-7 mAbs. This suggests that MC3T3-E1 adhesion to RGD peptides is dominated by interactions with $\alpha_{v}$ integrins. The data points for samples with BMA-5 are omitted for clarity.

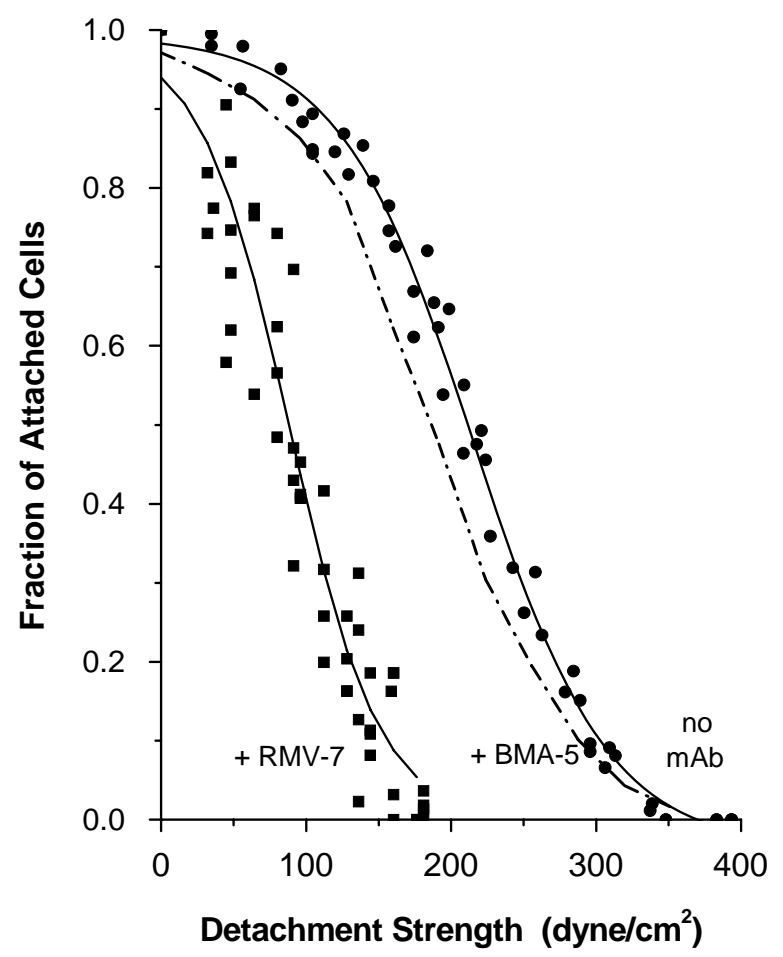


Lee, MH; Adams, CS; Boettiger, D; DeGrado, WF; Shapiro, IM; Composto RJ; Ducheyne, P., 2007, Adhesion and function of MC3T3-E1 cells on RGD peptides of different flanking residues: Detachment strength and correlation with long-term cellular function, JOURNAL OF BIOMEDICAL MATERIALS RESEARCH, PT.A., IN PRESS.

Figure 5. Spreading of MC3T3-E1 cells on peptide-modified substrates. The cells were labeled with DiI and the spread area was tracked using fluorescent microscopy. After 1h, the peptides with RGDS showed a significant increase in spread area over those of the BMPSOH and RGES controls $(\mathrm{p}<0.05)$. The difference between the three RGDS peptides was not significant at all times. Bars are means $\pm 95 \%$ Confidence Intervals $(n=9)$.

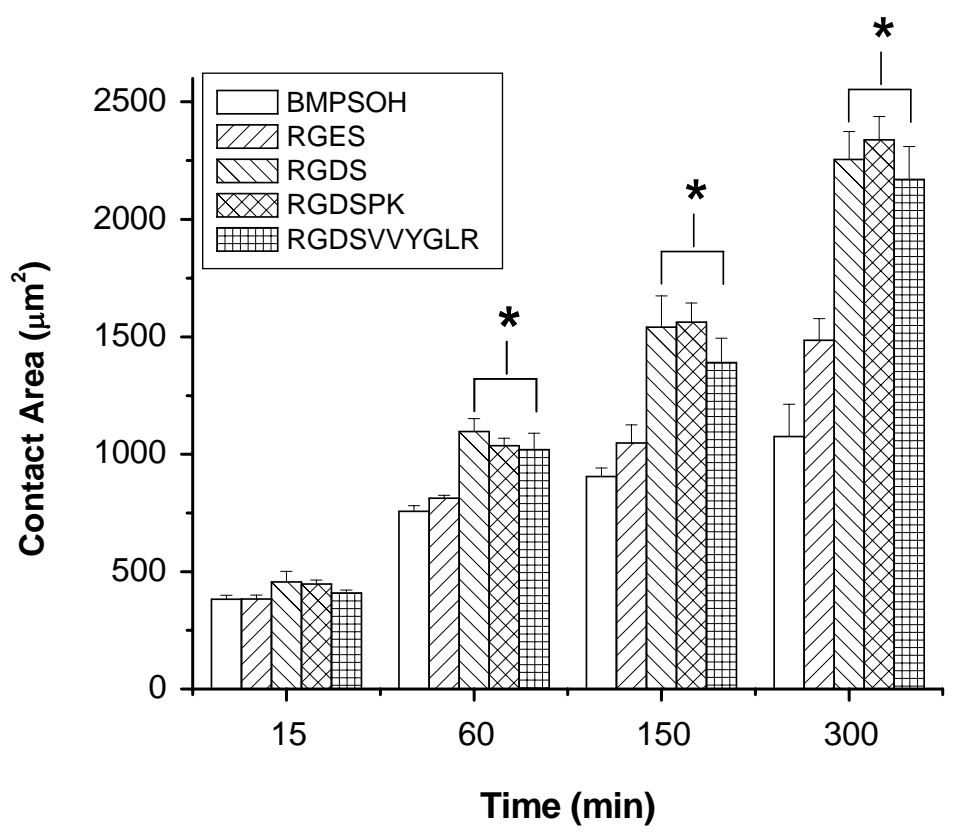


Lee, MH; Adams, CS; Boettiger, D; DeGrado, WF; Shapiro, IM; Composto RJ; Ducheyne, P., 2007, Adhesion and function of MC3T3-E1 cells on RGD peptides of different flanking residues: Detachment strength and correlation with long-term cellular function, JOURNAL OF BIOMEDICAL MATERIALS RESEARCH, PT.A., IN PRESS.

Figure 6. Alkaline phosphatase (ALP) activity of MC3T3-E1 cells on peptide modified substrates cultured in osteogenic medium after 8,11 and 15 days. ALP of cells cultured on Fn was the highest at all times. ALP of cells on RGDSPK became significant by 11 days and maintained similar levels as Fn until 15 days. RGDS and RGDSVVYGLR did not produce significant increases in ALP until 15 days. Bars are means \pm 95\% Confidence Intervals $(n=9)$. Asteriks denote significant increases $(\mathrm{p}<0.05)$ over the RGES control of the same time period.

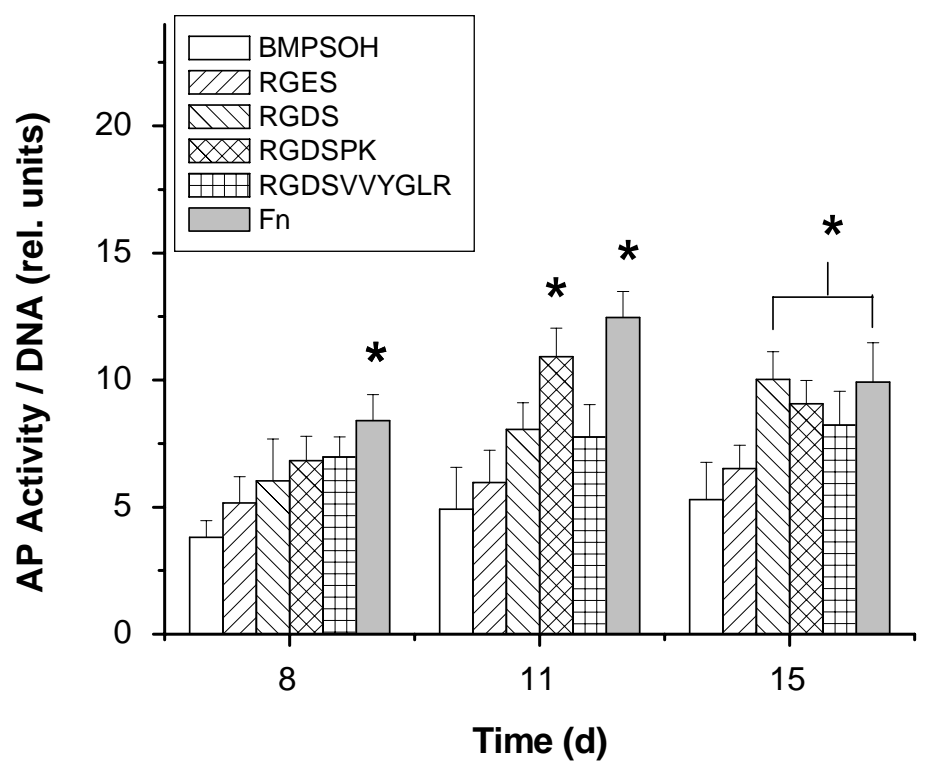


Lee, MH; Adams, CS; Boettiger, D; DeGrado, WF; Shapiro, IM; Composto RJ; Ducheyne, P., 2007, Adhesion and function of MC3T3-E1 cells on RGD peptides of different flanking residues: Detachment strength and correlation with long-term cellular function, JOURNAL OF BIOMEDICAL MATERIALS RESEARCH, PT.A., IN PRESS.

Figure 7. Digital photographs of representative alizarin Red-S stained peptide-modified substrates after 11, 15 and 24 days in culture. The light areas represent the calcified deposits. After 15 days, the RGDS and RGDSPK showed noticeable deposits of mineral. By 24 days, all RGDS-containing peptides showed significant degrees of mineralization which were higher than the RGES control. The size of each image is $1 \mathrm{~cm} \times 1 \mathrm{~cm}$.

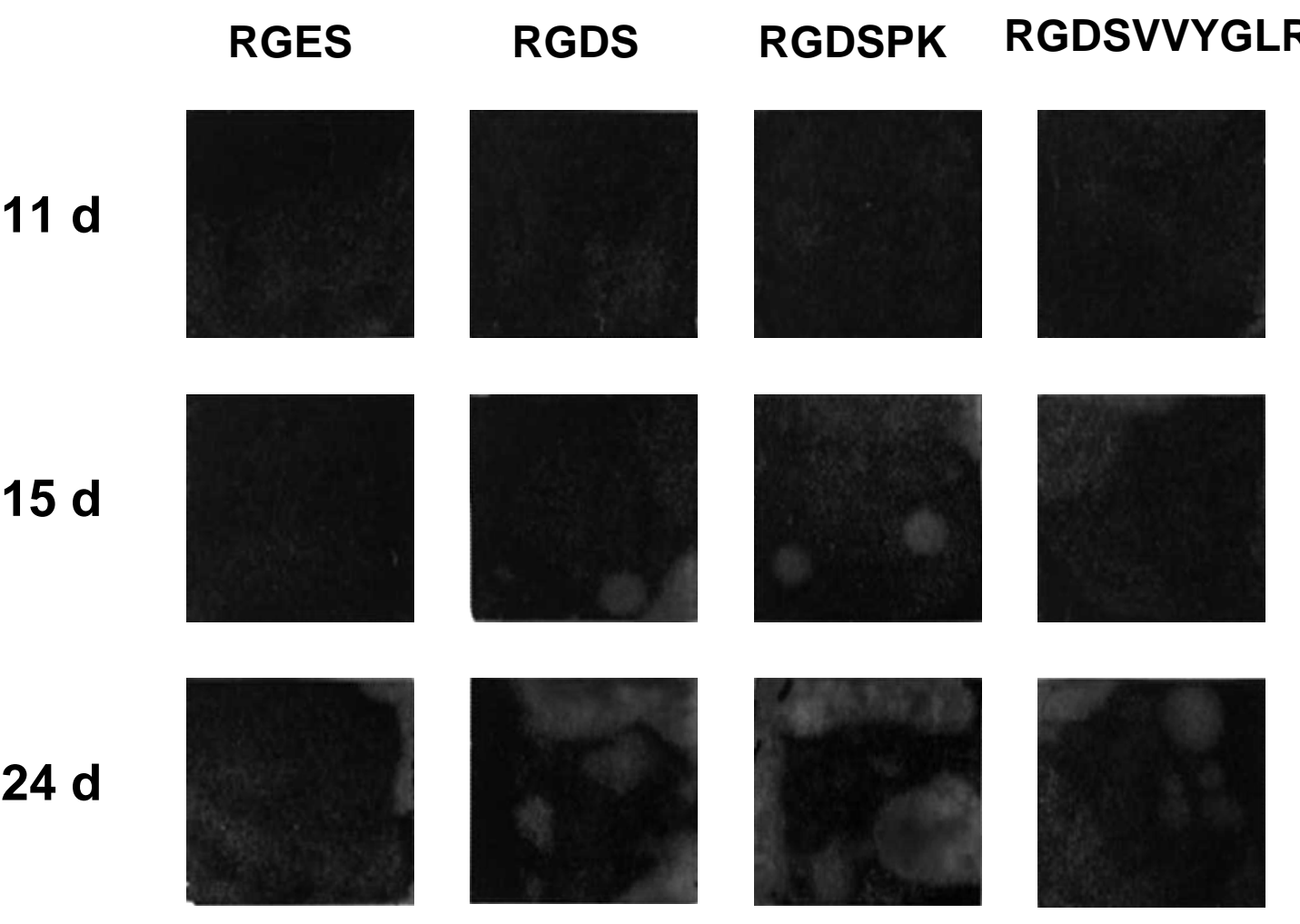


Lee, MH; Adams, CS; Boettiger, D; DeGrado, WF; Shapiro, IM; Composto RJ; Ducheyne, P., 2007, Adhesion and function of MC3T3-E1 cells on RGD peptides of different flanking residues: Detachment strength and correlation with long-term cellular function, JOURNAL OF BIOMEDICAL MATERIALS RESEARCH, PT.A., IN PRESS.

Figure 8. Quantification of calcified mineral on samples after 8, 11, 15 and 24 days in culture. Cells cultured on Fn produced the most mineralization after 8 days. There were significant increases in the minerals on RGDS and RGDSPK after 15 days. By 24 days, all RGDScontaining peptides produced significant increases in mineralization and reached comparable levels as Fn. Bars are means $\pm 95 \%$ Confidence Intervals $(n=9)$. Asteriks denote significant increases $(\mathrm{p}<0.05)$ over the RGES control of the same time period.

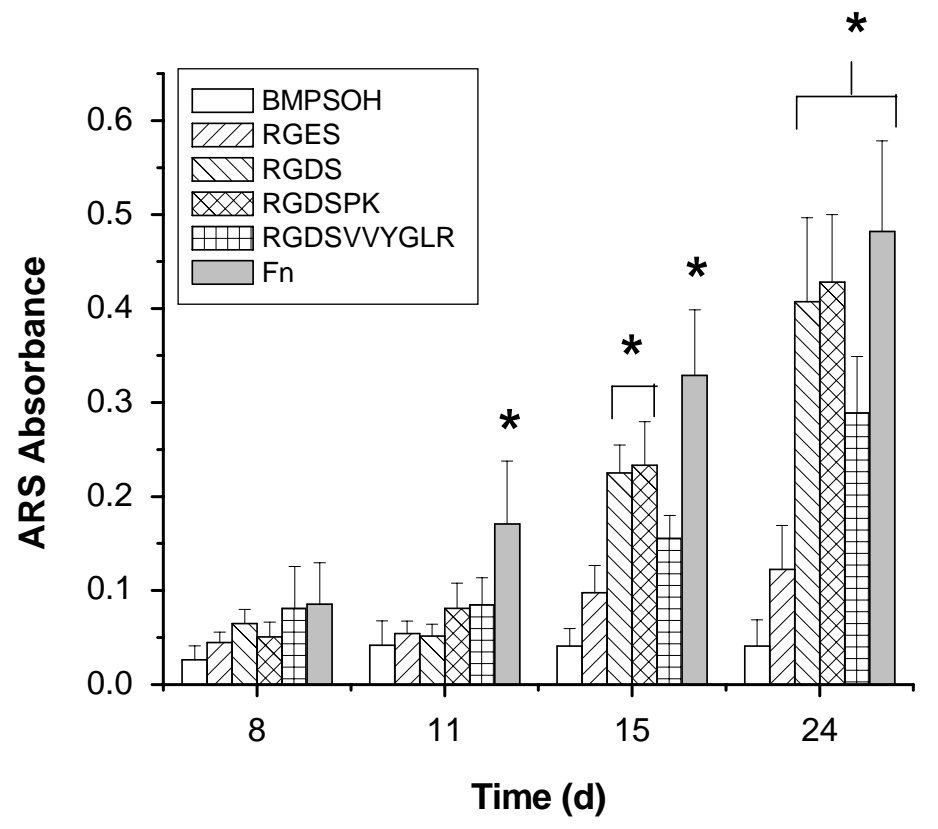

